\title{
Influence of Natural Surface Ageing on Bonding Qualify of Thermally Modified Oak and Beech Wood
}

\section{Utjecaj prirodnog starenja površine na kvalitetu lijepljenja toplinski modificiranog drva hrasta i bukve}

\author{
Original scientific paper • Izvorni znanstveni rad \\ Received-prispjelo: 17. 3. 2019. \\ Accepted-prihvaćeno: 4. 7. 2019. \\ UDK: $630 * 812.74 ; 630 * 824.331$ \\ https://doi.org/10.5552/drvind.2019.1918
}

\begin{abstract}
This paper presents the influence of natural surface ageing in indoor conditions on bonding quality of thermally modified wood used in structural laminated products. Two unmodified and thermally modified wood species were used for the experiment: oak and beech. Samples were planed and glued with MUF adhesive 2 hours, 1, 2, 6, 10, and 18 days after planing. Properties of laminated beech and oak beams, namely shear strength, delamination and contact angle, were measured in order to detect 1) suitability of wood species for lamination process and 2) influence of extended storage time after planing on properties of laminated wood. Generally, both native and thermally modified beech exhibited better results of shear strength and delamination and had lower contact angles compared to oak and thermally modified oak. Results of the delamination test (total delamination) indicate time dependence of surface ageing. Both unmodified and thermally modified beech may be successfully laminated at least up to 2 days after planing, whereas neither oak nor thermally modified oak are suitable for lamination process due to excessive delamination. Results of delamination may be related to contact angle measurements. Shear strength of glue lines did not show any influence on natural surface ageing. However, whereas beech and thermally modified beech samples exhibited almost the same values of the shear strength regardless of the duration of surface ageing, there is an obvious difference in shear strength of oak and thermally modified oak samples.
\end{abstract}

Keywords: bonding, delamination, modified wood, shear strength, surface ageing

SAŽETAK • U radu je prikazan utjecaj prirodnog starenja površine zbog stajanja u interijeru na kvalitetu lijepljenja toplinski modificiranog drva. U pokusu su korištene dvije nemodificirane i toplinski modificirane vrste drva: hrast i bukva. Uzorci su blanjani i lijepljeni MUF ljepilom 2 sata, 1, 2, 6, 10 i 18 dana nakon blanjanja. Mjerena su svojstva lameliranih bukovih i hrastovih gredica, njihova čvrstoća na smik, delaminacija i kontaktni kut kako bi se ustanovila (1) prikladnost vrste drva i postupka modifikacije za proces lameliranja te (2) utjecaj produljenog vremena skladištenja nakon blanjanja na svojstva lameliranog drva. Općenito, i prirodna i toplinski modificirana bukovina pokazale su bolje rezultate smične čvrstoće i manju sklonost delaminaciji, kao i niže kontaktne kutove nego hrastovina i toplinski modificirana hrastovina. Rezultati ispitivanja delaminacije (potpune delaminacije) upućuju na ovisnost površinskog starenja o vremenu. I nemodificirana i toplinski modificirana bukov-

\footnotetext{
Authors are assistant professor, student and associate professor at University of Zagreb, Faculty of Forestry, Zagreb, Croatia.

Autori su docent, student i izvanredni profesor Sveučilišta u Zagrebu, Šumarski fakultet, Zagreb, Hrvatska.
} 
ina mogu se uspješno lamelirati najmanje dva dana nakon blanjanja, dok ni hrastovina ni toplinski modificirana hrastovina zbog sklonosti prekomjernoj delaminaciji nisu prikladne za lameliranje. Rezultati delaminacije mogu biti povezani s mjerenjima kontaktnog kuta. Čvrstoća lijepljenja na smik nije uvjetovana prirodnim starenjem površine. Međutim, dok su nemodificirani i toplinski modificirani uzorci bukve imali gotovo jednake vrijednosti čvrstoće lijepljenja na smik bez obzira na trajanje površinskog starenja, bila je očita razlika u smičnoj čvrstoći hrastovih nemodificiranih i toplinski modificiranih uzoraka.

Ključne riječi: lijepljenje, delaminacija, modificirano drvo, smična čvrstoća, starenje površine

\section{INTRODUCTION}

\section{UVOD}

It is well known that bonding quality of wood depends not only on the type and quality of the adhesive and parameters of the technological process, but also on the condition of the wood material and especially of its surface. For optimal results, adhesive should be applied to wood surface within 24 hours after the surface is prepared (by planing or sanding), as this ensures the removal of extractives and other physical and chemical contaminants from the surface (Vick, 1999). Surface wettability is linearly reduced during $4-6$ days, which may negatively affect the bonding strength (Nussbaum, 1999). A lot of attention was given to establishing the influence of specimen size (especially lamella width and thickness), the alignment of the annual rigs in the lamellas, closed assembly time and pressure on bond durability (Aicher and Reinhardt, 2007; Schmidt et al., 2010). Adhesive penetration into wood was reviewed in detail by Kamke and Lee (2007), who identified several important factors; these are fluid properties of the resin, anatomical characteristics and permeability of wood, and processing conditions. Penetration of adhesive is particularly important because it needs to be sufficient to encapsulate damaged cells near the bonded interface, but not excessive in order to eliminate waste of resin and low mechanical properties if bondline remained starved.

Thermally modified wood has many applications both indoors and outdoors, mainly for decorative purposes and non-load bearing structures. The degradation of mechanical properties during treatment at high temperatures requires additional tests before the material can be used for load bearing purposes (Borrega and Kärenlampi, 2008). However, thanks to its good biological resistance and aesthetic attributes (Hill, 2006), it is an attractive building material.

Thermal modification process also reduces the surface wettability and increases surface brittleness, which then negatively affects bond performance of wood (Chu et al., 2016; Šernek et al., 2008; Kariž and Šernek, 2012; Uzun et al., 2016). However, shear strength and delamination tests performed on native and thermally modified Norway spruce and poplar glued with PUR and MUF adhesives were found to meet the requirements for glued laminated timber (Šernek et al., 2008). Additionally, surface structure of hardwoods (ring-porous oak wood and diffuse to semi-ring-porous beech) might additionally affect the bonding quality. Experiments performed on ash wood laminated with differ- ent structural adhesives showed that shear strength of bonded ash is comparable with that of solid ash, but resistance to delamination could not be met by any of the adhesives (Knorz et al., 2014). Widmann et al. (2012) investigated the influence of thermal treatment at 180 $190^{\circ} \mathrm{C}$ on structural beech wood. The treatment resulted in a significant reduction of most strength properties the strength properties perpendicular to grain suffered a lot, brittle behaviour of the specimens and big variations in strength were detected as the main disadvantages of thermal treatment, whereas compression strength parallel to grain and stiffness properties were unchanged. Based on these results, a general use of thermally modified beech as structural timber was not recommended, except for structural facade elements or for columns. Testing of glulam beams made of thermally modified beech timber (Widmann et al., 2014) showed sufficient quality of manually produced finger-joints, poor 4-point bending strength, but high stiffness, high degree of delamination and good shear properties with over $80 \%$ wood failure.

Hardwoods (especially oak) are challenging for both thermal modification and gluing. Some companies put modified and mechanically prepared material on stock, which may then affect negatively the bonding properties. Therefore, the aim of our paper was to investigate the influence of natural surface ageing of both native and thermally modified oak and beech wood in indoor conditions on bonding quality in structural applications.

\section{MATERIALS AND METHODS} 2. MATERIJALI I METODE

Two wood species were used for the experiment: oak (Quercus robur L.) (O, OT) and beech (Fagus sylvatica) (B, BT). The material for testing was flat sawn and commercially thermally modified by a local manufacturer at $210{ }^{\circ} \mathrm{C}$ in water vapor atmosphere. Unmodified and thermally modified samples of $1000 \mathrm{~mm} \times 100$ $\mathrm{mm} \times 20 \mathrm{~mm}(\mathrm{~L} \times \mathrm{T} \times \mathrm{R})$ were planed and glued with MUF adhesive 2 hours, 1, 2, 6, 10, and 18 days after planing. Each beam consisted of 5 lamellae. The adhesive was applied in industrial conditions using rollers. Application rate of the adhesive was $180 \mathrm{~g} / \mathrm{m}^{2}$ per side (360 g/m $\mathrm{m}^{2}$ in total), pressure $1.5 \mathrm{MPa}$, pressing time 16 hours. Pressing was performed at normal ambient conditions. After curing of the adhesive, beams were cut into 5 test pieces of $75 \mathrm{~mm} \times 100 \mathrm{~mm} \times 100 \mathrm{~mm}(\mathrm{~L} \times \mathrm{T} \times \mathrm{R})$ for delamination tests and 10 test bars of $40 \mathrm{~mm} \times 40$ $\mathrm{mm} \times 100 \mathrm{~mm}(\mathrm{~L} \times \mathrm{T} \times \mathrm{R})$ for shear strength tests 


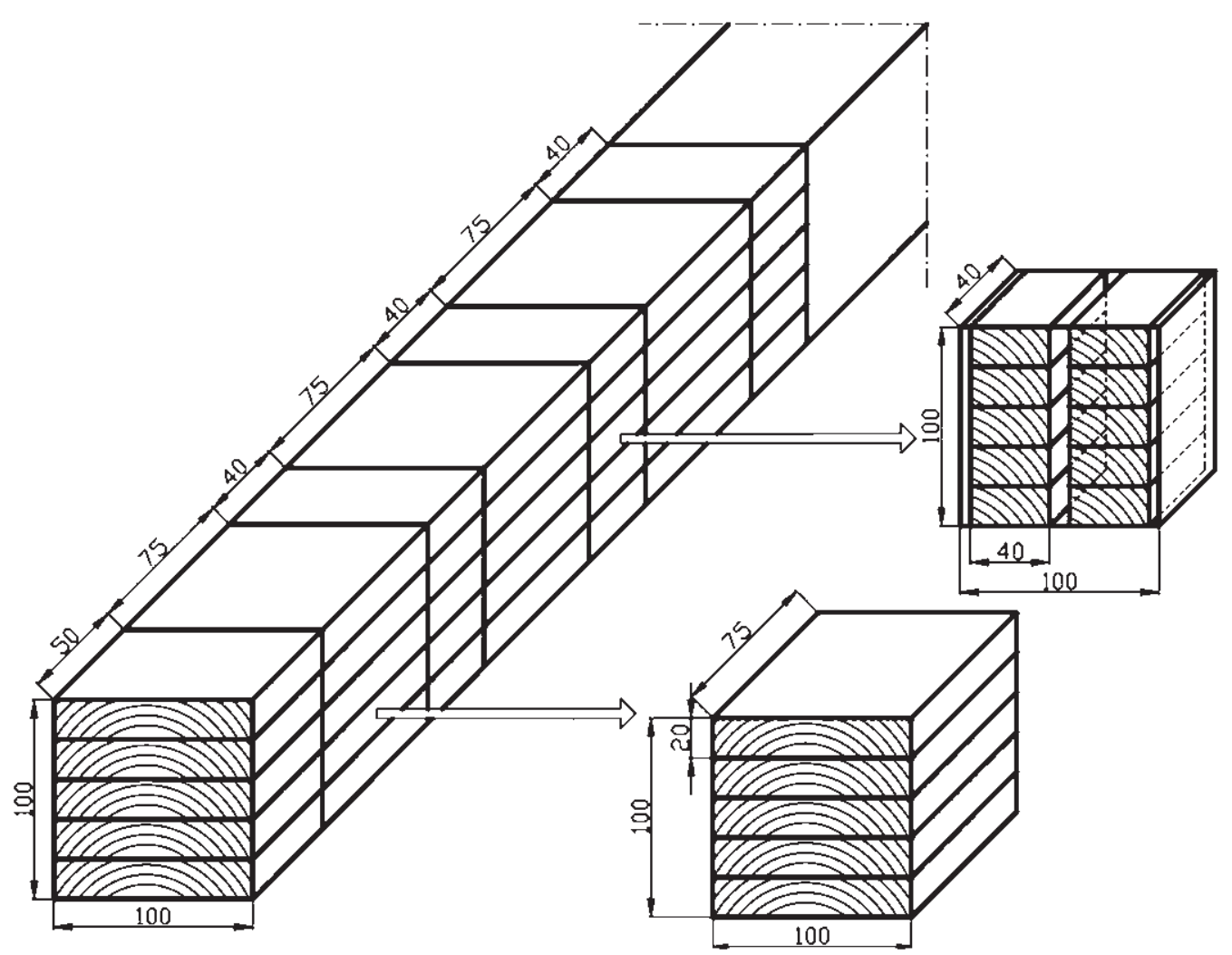

Figure 1 Cutting scheme of experimental beams for delamination and shear tests

Slika 1. Shema izrezivanja ispitnih uzoraka za potrebe ispitivanja čvrstoće na smik i delaminacije

(scheme shown in Figure 1). An additional set of samples was used for contact angle measurements.

Contact angle of distilled water was measured using a sessile drop method with an optical goniometer. Drops of $2 \mu \mathrm{L}$ were observed using a digital camera installed on the opposite side of the light source. Droplets were applied at 10 different places on tangential surfaces on each specimen, and images for contact angle were taken 3 seconds after detachment of the drop.

The samples for the delamination test were fully impregnated with water within a single cycle process that consisted of 30 min vacuum of $85 \mathrm{kPa}$ that was followed by 2 hours pressure of $600 \mathrm{kPa}$. After this intensive impregnation step, the samples were placed into the drying duct at $70{ }^{\circ} \mathrm{C}$ and $10 \% \mathrm{RH}$ to reach $110 \%$ of the original mass. Delamination is expressed as percentage of the total bondline length. Details of this method are given in EN 14080:2013 Annex C, method B.

Shear test of glue lines was performed using a compression-loading shear tool on universal testing machine with continuous shearing speed. Shear strength was then calculated for each individual bondline based on the ratio of maximum load at failure and shear areas according to EN 14080:2013.

All the measurements were taken after conditioning the samples in standard laboratory conditions $(20 \pm 2){ }^{\circ} \mathrm{C}$ and $(65 \pm 5) \% \mathrm{RH}$.

\section{RESULTS AND DISCUSSION}

\section{REZULTATI I RASPRAVA}

Contact angle continuously increased with surface ageing over the period of 10 days (Figure 2). At all the stages of ageing, the contact angle was lowest in the case of unmodified beech (B: $24-41^{\circ}$ ), oak (O: 50 $-65^{\circ}$ ), thermally modified beech (BT: $50-65^{\circ}$ ) and highest in the case of thermally modified oak (OT: 64 $\left.-76^{\circ}\right)$. This is in accordance with the results of Žlahtič and Humar (2016), who have also reported higher contact angles on oak compared to beech wood. Increase of the contact angles on beech wood samples subjected to thermal modification was reported earlier by several researchers (Gérardin et al., 2007; Miklečić and JiroušRajković, 2016; Pétrissans et al., 2003; Žlahtič and Humar, 2016). However, due to differences in methodology of contact angle measurement, it is hard to compare individual values (Petrič and Oven, 2015).

Results of total delamination clearly show the influence of both wood species and thermal treatment as well as the time dependence of surface ageing (Figure 3 ). There is relatively small delamination during the first 2 days of natural surface ageing in the case of unmodified and modified beech and unmodified oak. However, if lamination is performed later than 2 days after planing, the delamination exceeds the maximum value set by EN 14080. At the same time, delamination of thermally modified oak is too excessive regardless of the duration of surface ageing, indicating that this species is not suitable for laminations under conditions presented in this experiment.

Both unmodified and thermally modified beech may, therefore, be successfully laminated for at least up to 2 days after planing, whereas neither oak nor thermally modified oak are suitable for the lamination process under conditions presented here. According to EN 14080:2013, when the glue line integrity is tested 


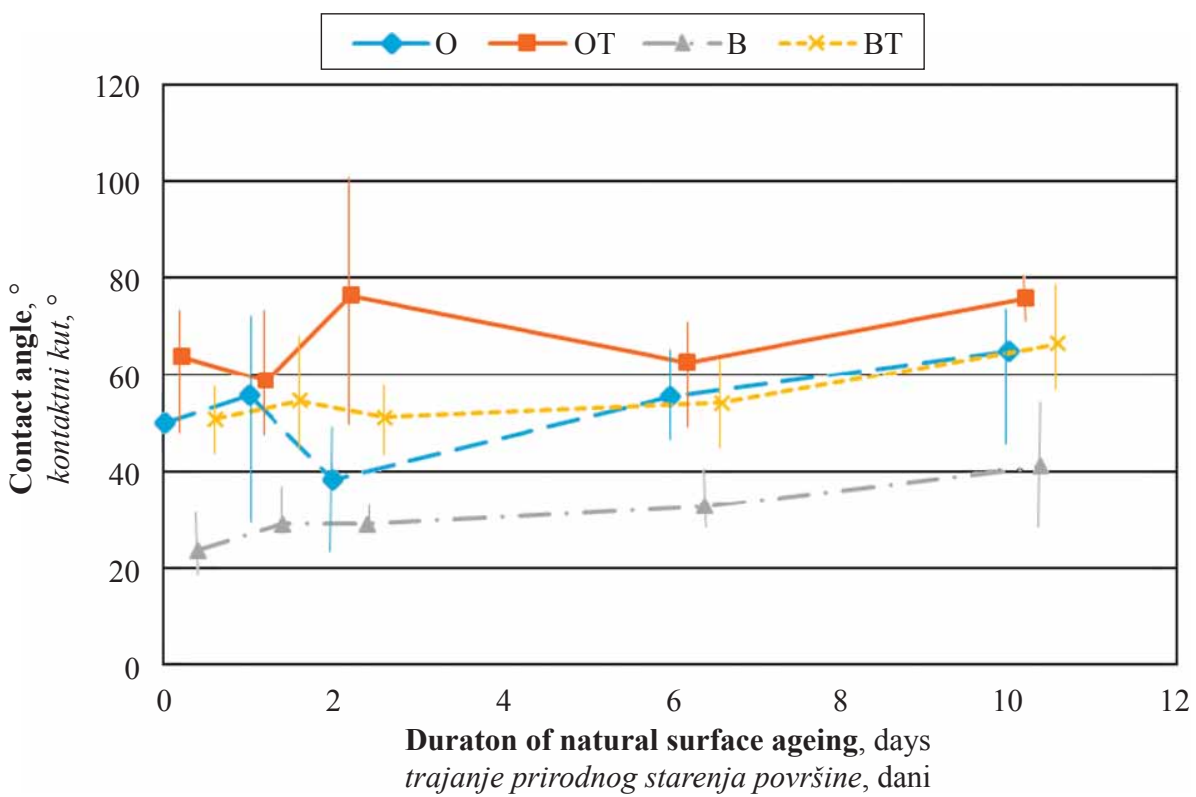

Figure 2 Influence of duration of natural surface ageing on contact angle measurements Slika 2. Utjecaj vremena prirodnog starenja površine na vrijednosti kontaktnog kuta

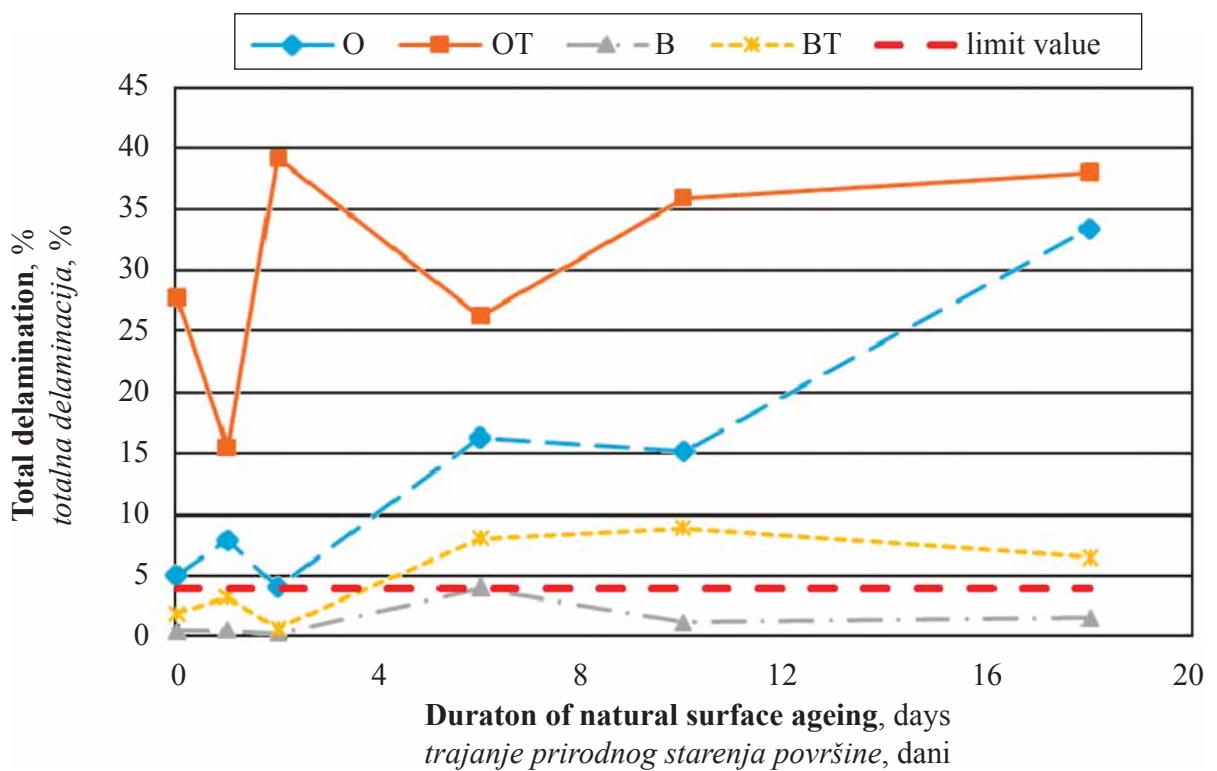

Figure 3 Influence of duration of natural surface ageing on total delamination

Slika 3. Utjecaj vremena prirodnog starenja površine na potpunu delaminaciju

by delamination test (method B), the total delamination after one cycle should not exceed $4 \%$.

Results of delamination may be related to contact angle measurements, which indicated that freshly prepared surface is easier to wet compared to naturally aged surface, but also that contact angle is lowest on beech $\left(20^{\circ}, 2\right.$ hours after planing) and highest on thermally modified oak surface $\left(\sim 76^{\circ}, 10\right.$ days after planing).

Shear strength of glue lines in dry conditions did not depend on surface ageing, and the results for each set of samples for a specific species are in very narrow range (Figure 4). Shear strength is lowest in the case of thermally modified oak $\left(\sim 11 \mathrm{~N} / \mathrm{mm}^{2}\right)$ and unmodified oak $\left(\sim 15.5 \mathrm{~N} / \mathrm{mm}^{2}\right)$, whereas the shear strength values are very similar in case of unmodified and thermally modified beech $\left(\sim 20 \mathrm{~N} / \mathrm{mm}^{2}\right)$. The shear test showed $>$ $95 \%$ wood failure for all tested species and variables.
Šernek et al. (2008) recorded about $10 \%$ decrease of shear strength of glue lines and no delamination on heat treated Norway spruce with MUF adhesive. On the other hand, Knorz et al. (2014) tested structural bonding of ash wood with different adhesives including MUF. Ash is also a ring porous species and with similar density as oak wood, which makes the results comparable with those in this experiment. The results showed high wood failure and bond strength close to that of solid ash. However, resistance to delamination could not meet the requirements of the standard by any of the adhesives. Both, delamination and shear strengths correspond well with those obtained on oak in our experiment.

Here presented results clearly show the following: 1. Thermal modification process influenced the reduction of shear strength of glue lines of oak wood by 


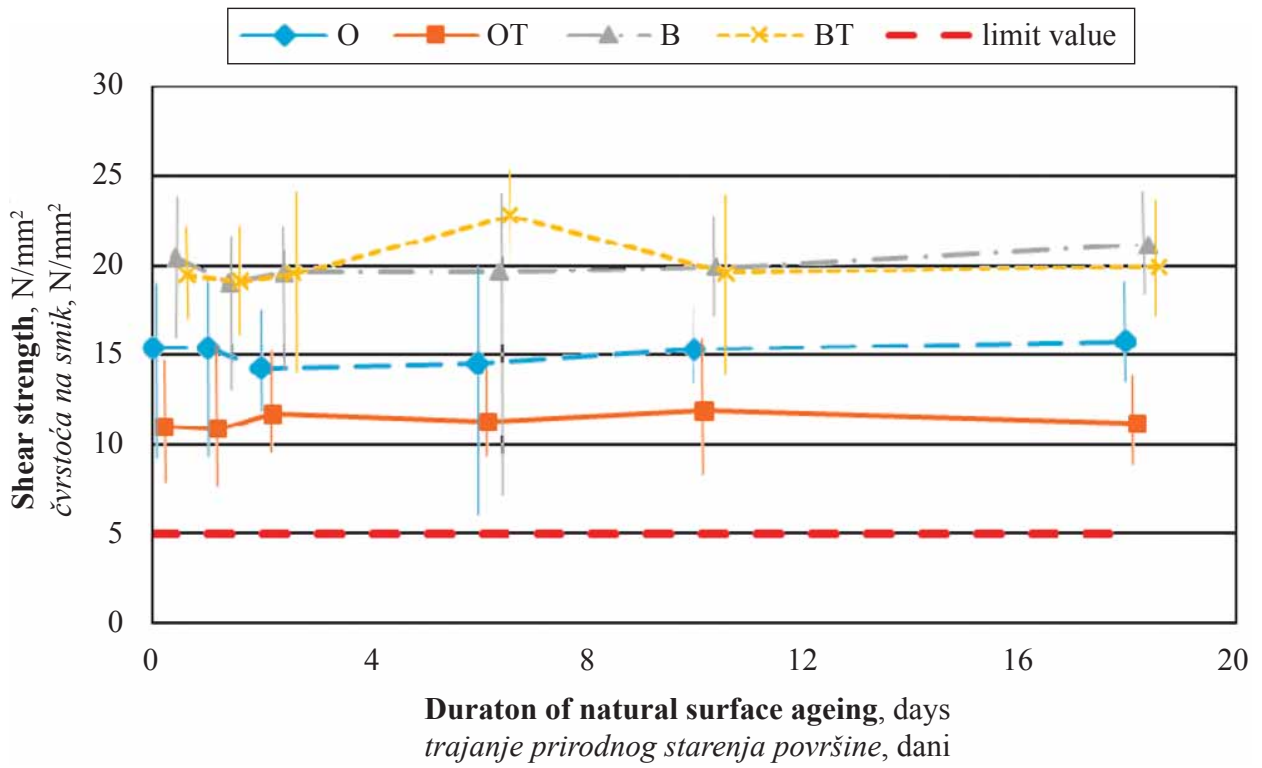

Figure 4 Influence of duration of natural surface ageing on shear strength

Slika 4. Utjecaj vremena prirodnog starenja površine na čvrstoću na smik

$30 \%$, but subsequent natural surface ageing had no effect on shear strength of glue lines.

2. There was no influence of either modification process or natural surface ageing on shear strength of glue lines of beech wood.

3. Based on shear test of glue lines, both unmodified and thermally modified beech and oak may be used in laminations for timber structures because they meet the requirements for minimum values as defined by EN 14080, according to which shear strength of each glue line is at least $6 \mathrm{~N} / \mathrm{mm}^{2}$ provided that minimum wood failure is at least $90 \%$.

No relation between shear strength and delamination could be seen. The same behaviour was reported earlier for unmodified beech and ash wood (Schmidt et al., 2010; Knorz et al., 2014).

\section{CONCLUSIONS}

\section{ZAKLJUČAK}

Generally, both unmodified and thermally modified beech exhibited better results compared to oak and thermally modified oak.

Results of the delamination test (total delamination) indicate a time dependence of surface ageing. Both native and thermally modified beech may be successfully laminated at least up to 2 days after planing, whereas neither oak nor thermally modified oak are suitable for lamination process under the above conditions.

Shear strength of glue lines did not show any influence of natural surface ageing. Average shear strength of glue lines (in dry conditions) indicates that both native and thermally modified beech and oak may be successfully laminated regardless of the duration of natural surface ageing. However, whereas beech and thermally modified beech samples exhibited almost the same values regardless of the duration of surface ageing $\left(\sim 20 \mathrm{~N} / \mathrm{mm}^{2}\right)$, there is an obvious difference in shear strength of oak $\left(\sim 15 \mathrm{~N} / \mathrm{mm}^{2}\right)$ and thermally modified oak samples $\left(\sim 11 \mathrm{~N} / \mathrm{mm}^{2}\right)$.

Results of delamination may be related to contact angle measurements, which indicated that freshly prepared surface is easier to wet compared to naturally aged surface, but also that contact angle is lowest on beech $\left(20^{\circ}, 2\right.$ hours after planing) and highest on thermally modified oak surface ( $64^{\circ}, 2$ hours after planing).

\section{Acknowledgements - Zahvala}

The authors wish to express their gratitude to Dr Marin Hasan for assistance with impregnation of the samples for delamination tests and to PPS Galeković company for preparation of the material for this experiment.

This research did not receive any specific grant from funding agencies in the public, commercial, or not-for-profit sectors.

\section{REFERENCES}

5. LITERATURA

1. Aicher, S.; Reinhardt, H. W., 2007: Delaminierungseigenschaften und Scherfestigkeiten von verklebten rotkernigen Buchenholzlamellen. Holz als Roh- und Werkstoff, 65: 125-136.

https://doi.org/10.1007/s00107-006-0135-7.

2. Borrega, M; Kärenlampi, P. P., 2008: Mechanical behavior of heat-treated spruce (Picea abies) wood at constant moisture content and ambient humidity. Holz als Rohund Werkstoff, 66: 63-69. https://doi.org/10.1007/s00107-007-0207-3.

3. Chu, D.; Xue, L.; Zhang, Y.; Kang, L.; Mu, J., 2016: Surface characteristics of poplar wood with high-temperature heat treatment: Wettability and surface brittleness. BioResources, 11 (3): 6948-6967.

https://doi.org/10.15376/biores.11.3.6948-6967.

4. Gérardin, P.; Petrič, M.; Petrissans, M.; Lambert, J.; Ehrhrardt, J. J., 2007: Evolution of wood surface free energy after heat treatment. Polymer Degradation and Stability, 92: 653-657.

https://doi.org/10.1016/j.polymdegradstab.2007.01.016. 
5. Hill, C., 2006: Wood modification - chemical, thermal and other processes. John Wiley \& Sons, Ltd.

6. Kamke, A. F.; Lee, J. N., 2007: Adhesive penetration in wood - a review. Wood and Fiber Science, 39: 205-220.

7. Kariž, M.; Šernek, M., 2012: Bonding of heat-treated spruce with PVAc, PU and MUF adhesives. In: Proceedings of the Sixth European Conference on Wood Modification. Jones, D.; Militz, H.; Petrič, M.; Pohleven, F.; Humar, M.; Pavlič, M. (eds.), Ljubljana, Slovenia, pp. 247-250.

8. Knorz, M.; Schmidt, M.; Torno, S.; van de Kuilen, J.-W., 2014: Structural bonding of ash (Fraxinus excelsior L.): resistance to delamination and performance in shearing tests. European Journal of Wood and Wood Products, 72: 297-309. https://doi.org/10.1007/s00107-014-0778-8.

9. Miklečić, J.; Jirouš-Rajković, V., 2016: Influence of thermal modification on surface properties and chemical composition of beech wood (Fagus sylvatica L). Drvna industrija, 67 (1): 65-71. https://doi.org/10.5552/drind.2016.1520.

10. Nussbaum, R. M., 1999: Natural surface inactivation of Scots pine and Norway spruce evaluated by contact angle measurements. Holz als Roh- und Werkstoff, 57 (6): 419424. https://doi.org/10.1007/s001070050067.

11. Petrič, M.; Oven, P., 2015: Determination of wettability of wood and its significance in wood science and technology: A critical review. Reviews of Adhesion and Adhesives 3(2): 121-187. https://doi.org/10.7569/RAA.2015.097304.

12. Pétrissans, M.; Gérardin, P.; El Bakali, I.; Serraj, M., 2003: Wettability of heat-treated wood. Holzforschung, 57: 301-307. https://doi.org/10.1515/HF.2003.045.

13. Schmidt, M.; Glos, P.; Wegener, P., 2010: Verklebung von Buchenholz für tragende Holzbauteile. European Journal of Wood and Wood Products, 68: 43-57. https://doi.org/10.1007/s00107-009-0382-5.

14. Šernek, M.; Boonstra, M.; Pizzi, A.; Despres, A.; Gerardin, P., 2008: Bonding performance of heat treated wood with structural adhesives. Holz als Roh- und Werkstoff, 66: 173-180. https://doi.org/10.1007/s00107-007-0218-0.
15. Uzun, O.; Perçin, O.; Altinok, M.; Kureli, I., 2016: Bonding strength of some adhesives in heat-treated hornbeam (Carpinus betulus L.) wood used for interior and exterior decoration. BioResources, 11 (3): 7686-7696. https://doi.org/10.15376/biores.11.3.7686-7696.

16. Vick, C. B., 1999: Adhesive bonding of wood materials. In: Wood Handbook: Wood as an Engineering Material. Forest Products Laboratory, pp. 9-1 - 9-24.

17. Widmann R.; Beikircher W.; Cabo J. L. F.; Steiger R., 2014: Bending strength and stiffness of glulam beams made of thermally modified beech timber. In: Aicher S.; Reinhardt H. W.; Garrecht, H. (eds,): Materials and Joints in Timber Structures. RILEM Bookseries, vol 9. Springer, Dordrecht. https://doi.org/10.1007/978-94-007-7811-5_52.

18. Widmann, R.; Fernandez-Cabo, J. L.; Steiger, R., 2012: Mechanical properties of thermally modified beech timber for structural purposes. European Journal of Wood and Wood Products, 70: 775-784. https://doi.org/10.1007/s00107-012-0615-x.

19. Žlahtič, M.; Humar, M., 2016: Influence of artificial and natural weathering on the hydrophobicity and surface properties of wood. BioResources, 11 (2): 4964-4989. https://doi.org/10.15376/biores.11.2.4964-4989.

20. ${ }^{* * *}$ EN 14080:2013 Timber structures - Glued laminated timber and glued solid timber - Requirements. Comité Européen de Normalisation CEN, Brussels, Belgium.

\section{Corresponding address:}

Assist. Prof. VJEKOSLAV ŽIVKOVIĆ, Ph.D.

University of Zagreb

Faculty of Forestry

Department for Furniture and Wood Products

Svetošimunska 25, 10002 Zagreb, CROATIA

e-mail: vzivkovic@sumfak.hr 